В. В. СВТУШЕНКО, С. О. КРАМАРЬОВ, В. О. ШАДРІН, Л. В. ЗАКОРДОНЕЦЬ (КИїв)

\title{
УРАЖЕННЯ ЕНДОТЕЛІЮ ПРИ ГОСТРИХ ІНФЕКЦІЙНИХ ЗАХВОРЮВАННЯХ У ДІТЕЙ ТА ЙОГО ОЦІНКА ЗА БІОМАРКЕРОМ Е-СЕЛЕКТИНОМ
}

\author{
Національний медичний університет ім. О. О. Богомольця <evv1972@gmail.com>
}

\begin{abstract}
Проведено пілотне дослідження біомаркера ураження ендотелію Е-селектину у 55 дітей з гострими інфекційними захворюваннями різної етіологіi. Показник Е-селектину достовірно корелював з інфекційно-токсичним шоком $(R p b=0,35 ; P=0,003)$ та маркером запального процесу, $C$-реактивним білком $(R=0,43 ; P=0,001)$. Рівень $E$-селектину не мав достовірного зв'язку з віком пацієнтів $(R=-0,197 ; P=0,369)$, статтю хворих $(R p b=0,08 ; P=0,585)$, лікуванням у відділенні інтенсивної терапї $(R p b=0,13$; $P=0,203)$, проведенням штучної вентиляції легень $(R p b=0,27 ; P=0,208)$, тривалістю стаціонарного лікування $(R=0,043 ; P=0,845)$, рівнями лактатдегідрогенази у сироватиі крові $(R=-0,09 ; P=0,49)$, лактату $(R=-0,015 ; P=0,945)$ та лейкоцитів крові $(R=0,153 ; P=0,475)$.
\end{abstract}

Ключові слова: інфекційні захворювання, ендотелій, ендотеліальна дисфункція, біомаркер, Е-селектин, діти.

Вступ. Ендотелій відіграє головну роль у підтриманні судинного гомеостазу, зокрема бере участь у регуляції проникності, судинного тонусу, запалення та гемостазу. При інфекційних захворюваннях ендотелій виступає бар'єром на шляху дисемінації збудника та відіграє ключову роль в реалізації імунної відповіді на агресію. Стимулом для активації ендотеліального бар'єра може бути взаємодія з патогенами або компонентами бактеріальної стінки, опосередковано через ендогенні компоненти імунної відповіді, а також внаслідок травматичного ушкодження, гіпоксії [3].

Серед поширених в дитячій інфекційній практиці хвороб досить детально вивчено механізм ендотеліальної дисфункції при менінгококовій інфекції. На відміну від інших бактеріальних патогенів, активація ендотеліоцитів при даній інфекції відбувається внаслідок комплексного впливу ендотоксину та власне самих мікроорганізмів [7]. Ліпополісахарид (ЛПС) менінгококів складається з трьох структурних компонентів: олігосахаридного ядра, бічних ланцюжків полісахаридів (O) і ліпіду А. Саме ліпід А вважають відповідальним за прозапальну активність ЛПС. Після взаємодії ЛПС із специфічним рецептором (білок, що приєднує ЛПС) сигнал активації передається через рецептори CD14, TLR4 та MD2. У подальшому через індукування факторів транскрипції NF-кB та AP-1 активуються прозапальні цитокіни та здійснюється ендоцитоз ЛПС [19]. Крім того, самі менінгококи здатні приєднуватись до ендотеліальних клітин і утворювати колонії на їх поверхні. Головну роль в адгезії відіграють мікроворсинки типу IV (type IV pili, Tfp). Вони забезпечують приєднання поодиноких бактерій до люмінальної поверхні епітеліоцитів. У подальшому ці самі мікроворсинки взаємодіють з іншими бактеріями та спричинюють утворення великих колоній. Вважають, що менінгококи користуються зонами приєднання, призначеними для лейкоцитів. Адгезія бактерій викликає перерозподіл у клітинах ендотелію молекул ICAM-1, VCAM-1, E-selectin та CD44. За рахунок втягнення мікроворсинок ущільнюється контакт колоній бактерій з поверхнею епітеліоцитів. Після адгезії Тfр взаємодіють з $\beta$-2 адренорепторами. Їхня активація супроводжується зміною цитоскелета та формуванням вип’ячувань мембрани, які ще більше захищають колонії бактерій на поверхні клітини, а також міграцією білків, що формують щільні з'єднання (Tightjunctions), до місця приєднання менінгококів. Дефіцит цих білків, а також руйнування металопротеїназою ММР-8 білка оклюдину призводить до збільшення проникності щільних з'єднань і розвитку капілярного витоку. Для подолання гематоенцефалічного бар'єра, імовірніше, менінгококи використовують пошкоджені щільні з'єднання та/або трнспортуються у вакуолях за рахунок індукованого адгезією 
транцитозу. Порушуючи щільність ендотеліального шару, менінгококи також провокують розвиток геморагій і посилюють агрегацію лейкоцитів. Масивність колонізації судинного русла впливає на прояви пурпури та тяжкість шоку [5].

При грипі - однієї з найпоширеніших респіраторних інфекцій - взаємодія вірусів з ендотелієм також відіграє ключову роль в розвитку тяжких форм захворювання. Після первинного інфікування клітин респіраторного епітелію віруси грипу викликають пошкодження ендотеліального бар'єра. Важливе значення при цьому має збільшення концентрації хемокінів, зокрема підвищення рівня фактора некрозу пухлин (ФНП) при грипі через активацію Rho-кінази індукує апоптоз ендотеліоцитів. Високі рівні TNF, IL-6 та IL-1 $\beta$ активують трипсин, що руйнує білки щільних з'єднань та призводить до підвищення судинної проникності і посилення капілярного витоку. Продукування цитокінів також стимулює адгезивну функцію ендотелію. Міграція лейкоцитів в зону вторгнення звичайно є провідним елементом вродженої імунної відповіді на інфекцію. Проте відомо, що надмірна інфільтрація нейтрофільних гранулоцитів та утворення ними масивних позаклітинних пасток (neutrophilextracellulartraps, NETs) пов'язані з гострим ураженням легень і розвитком респіраторного дистрес-синдрому. Крім того, пошкодження ендотелію при грипі може мати тромботичну активність. Серед госпіталізованих дорослих пацієнтів з інфекцією H1N1pdm09 венозні та артеріальні тромбози виявляли майже у 6 \%. Процес тромбоутворення, з одного боку, стимулюється цитокінами, які індукують інгібітор активатора плазміногену (type 1 plasminogenactivatorinhibitor, PAI-1) і фактор активації тромбоцитів (plateletactivatingfactor, PAF), а 3 другого, гіпоксія при тяжких формах грипу запускає в клітинах ендотелію експресію прозапальних факторів, зокрема IL-1, IL-6, PAF, ICAM, Selectin, and VWF, кожен з яких має протромботичну активність [2].

При первинній VZV-інфекції, яка звичайно маніфестує у вигляді вітряної віспи, згідно із сучасними уявленнями, проходження вірусу через ендотеліальний бар’єр не потребує активної участі молекул адгезії E-selectin, ICAM-1 та VCAM-1. Вважають, що вірус транспортується з тонзилярної тканини до епідермісу в складі CD4+ Т-клітин пам'яті і проходить шар ендотелію шляхом діапедезу. Активна експресія молекул E-selectin, ICAM-1 та VCAM-1 на поверхні ендотелію починається лише після реплікації вірусу в клітинах шкіри та появи елементів висипання. Активація ендотелію, хоч із запізненням, необхідна для реалізації імунної відповіді й успішного припинення інфекційного процесу [10].

Активна роль ендотелію при інфекційних захворюваннях дозволяє розглядати його функціональні порушення як показник активності та тяжкості інфекційного процесу. Останніми роками активно вивчають значення біохімічних маркерів ендотеліальної дисфункції і їх можливості застосування в клінічній практиці. Зокрема, вивчають роль біомаркерів активності ендотеліальних клітин (angiopoietins-1 та -2), компоненти коагуляційного каскаду (von Willebrand Factor, ADAMTS13 та thrombomodulin), розчинні клітинні молекули адгезії (E-selectin, sICAM-1 i sVCAM-1), регулятори судинного тонусу і проникності (VEGF and sFlt-1). Нині існують публікації про суттєві зміни ендотеліальних біомаркерів у дітей, хворих на малярію, лихоманку Денге, а також про предиктивне значення летального наслідку у дітей з гострими захворюваннями з гарячкою [11].

Мета дослідження - вивчення рівня біомаркера ендотеліальної дисфункції Е-селектину в сироватці крові дітей з інфекційними захворюваннями різної етіології для оцінки ендотеліальної дисфункції та діагностичних можливостей цього показника.

Матеріали і методи. Обстежено дітей віком від 1 міс до 18 років, які проходили стаціонарне лікування в Київській міській дитячій інфекційній лікарні (КМДКІЛ) протягом січня-липня 2015 р. Під час комплексного обстеження хворих протягом першої доби перебування в стаціонарі визначали Е-селектин в сироватці крові методом імуноферментного аналізу. Дослідження проводили на аналізаторі "Sunrise Tесаn”. Застосовували набір "Human sE-selectin Platinum ELISA, eBioscience” з робочим діапазоном вимірювань 0,8-50 нг/мл, чутливістю 0,3 нг/мл та коефіцієнтом варіації 5,4 \%. 
Результати та іх обговорення. Обстежено 55 дітей віком від 1 міс до 17,7 року, хлопчиків було 25 (45,5 \%) та дівчат 30 (54,5 \%). У 31 (56,4 \%) дитини діагностовано бактеріальний менінгіт, в тому числі у 10 - менінгококової етіології, у 2 пневмококової та у 19 збудник не встановлено. В 11 (35,5 \%) пацієнтів встановлено діагноз менінгококцемії, в тому числі у 7 хворих спостерігали комбіновану форму з менінгітом. В 11 (20,0 \%) дітей встановлено діагноз гострої респіраторної вірусної інфекції, у 6 (10,9 \%) - енцефаліту, у 7 (12,7 \%) - асептичного менінгіту. У 54 (98,2 \%) дітей захворювання завершилось повним одужанням і у 1 пацієнта з менінгококцемією - летально.

Середній рівень Е-селектину у хворих становив $(11,93 \pm 13,70)$ нг/мл $(\mathrm{M} \pm \mathrm{SD})$, у пацієнтів з гострими респіраторними захворюваннями - $(6,21 \pm 6,59)$ нг/мл, у дітей з бактеріальним менінгітом - $(15,91 \pm 14,64)$ нг/мл, з ізольованою формою менінгококцемії - $(24,98 \pm 19,03)$ нг/мл, з асептичним менінгітом - $(6,06 \pm$ $5,15)$ нг/мл, з енцефалітом - $(4,22 \pm 5,28)$ нг/мл (рис. 1).

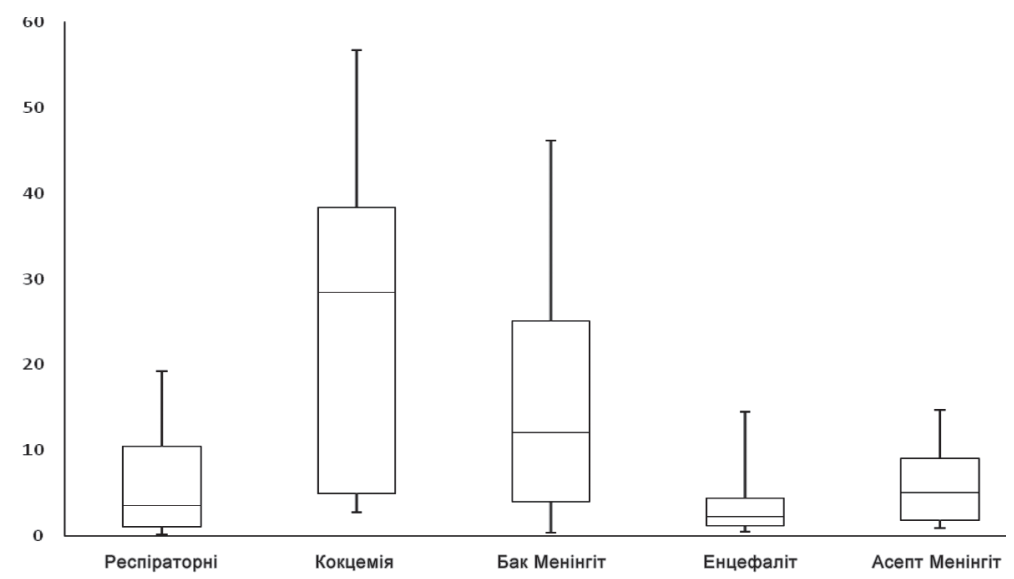

Рис. 1. Рівень Е-селектину у досліджуваних пацієнтів, нг/мл

У дітей з менінгококовим менінгітом (без менінгококцемії) рівень Е-селектину становив $(16,51 \pm 15,08)$ нг/мл, у хворих з комбінованими формами (менінгіт + менінгококцемія $)$ - $(21,43 \pm 17,47)$ нг/мл, у пацієнтів з бактеріальним менінгітом без менінгококкцемії - $(12,28 \pm 12,47)$ нг/мл (рис. 2).

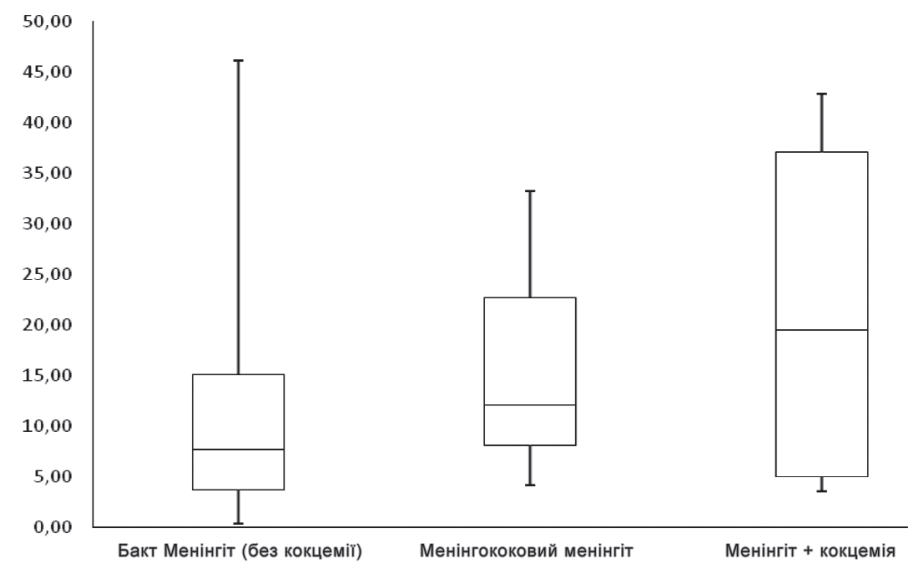

Рис. 2. Рівень Е-селектину у пацієнтів з бактеріальним менінгітом, нг/мл

Виявлено достовірну різницю за рівнем цього показника між групою хворих 3 комбінованою формою менінгококової інфекції (менінгіт + кокцемія) та респіраторними вірусними інфекціями ( $\mathrm{P}=0,0098$, за тестом Kruskal - Wallis), менінгітом бактеріальної етіології (без менінгококцемії) $(\mathrm{P}=0,046)$, енцефалітом 
$(\mathrm{P}=0,01)$, асептичним менінгітом $(\mathrm{P}=0,025)$. Між іншими групами пацієнтів достовірної різниці не встановлено.

Нами не виявлено зв'язку рівня Е-селектину з демографічними факторами, зокрема з віком пацієнтів (коефіцієнт рангової кореляції Спірмена $\mathrm{R}=-0,197$; $\mathrm{P}=0,369$ ), а також із статтю (точково-бісеріальний коефіцієнт кореляції $\mathrm{R}_{\mathrm{pb}}=0,08$; $\mathrm{P}=0,585)$. Показник Е-селектину достовірно корелював з інфекційно-токсичним шоком $\left(\mathrm{R}_{\mathrm{pp}}=0,35 ; \mathrm{P}=0,003\right)$, проте не залежав від перебування на лікуванні у відділенні інтенсивної терапії $\left(\mathrm{R}_{\mathrm{pb}}=0,13 ; \mathrm{P}=0,203\right)$, проведення штучної вентиляції легень (ШВЛ) $\left(\mathrm{R}_{\mathrm{pb}}=0,27 ; \mathrm{P}=0,208\right)$ та тривалості стаціонарного лікування $(\mathrm{R}=0,043 ; \mathrm{P}=0,845) .{ }^{\mathrm{pb}}$ Серед лабораторних показників рівень Е-селектину мав статистично достовірний зв'язок з показником C-реактивного білка - СРБ $(\mathrm{R}=0,43 ; \mathrm{P}=0,001)$ і разом з тим нами не виявлено кореляції з рівнями лактатдегідрогенази (ЛДГ) $(\mathrm{R}=-0,09 ; \mathrm{P}=0,49)$, лактату $(\mathrm{R}=-0,015 ; \mathrm{P}=0,945)$, лейкоцитів крові $(\mathrm{R}=0,153 ; \mathrm{P}=0,475)$.

Ендотелій кровоносних судин відіграє ключову роль в регуляції кровообігу, проникності судинної стінки, процесів коагуляції та запалення, реалізації функцій вродженого і набутого імунітету. Під час інфекційного процесу клітини ендотелію переходять в активний стан, що супроводжується експресією молекул адгезії (Е-селектин, ICAM-1, VCAM-1) на люмінальній поверхні ендотеліоцитів. Цей процес спричинюе втягнення лейкоцитів з кров'яного русла та їх міграції до зони ураження. Частина активованих молекул адгезії відокремлюється від клітинних мембран і надходить в кровообмін та може бути визначена лабораторними методами. Враховуючи, що наявність молекул адгезії в крові специфічно пов'язана 3 активацією ендотелію, останніми роками їх активно досліджують при різних захворюваннях у людей як діагностичні та прогностичні маркери.

Результати нашого дослідження свідчать, що рівень Е-селектину в сироватці крові був вищим у пацієнтів із септичним перебігом бактеріальних інфекцій (менінгіт, менінгококцемія), ніж із захворюваннями вірусної природи (ГРВІ, асептичний менінгіт, енцефаліт), а також при ускладненні інфекційно-токсичним шоком. Найвищі середні показники Е-селектину отримані нами у пацієнтів 3 менінгококцемією. На нашу думку, це пов'язано з тим, що серед спектра нозологій, які розглядали в даному дослідженні, саме при даній патології внаслідок дії ЛПС та масивної бактеріємії відбувається потужний вплив на ендотелій із залученням значного обсягу судинного русла. Оскільки відомо, що рівень СРБ асоціюється з тяжкістю бактеріальних інфекцій, то цілком логічною є кореляція рівня Е-селектину з даним маркером запальної реакції. При цьому ми не виявили асоціації рівня Е-селектину з лабораторними маркерами гіпоксії (лактат) та клітинного ураження (ЛДГ). Це дає підстави вважати, що провідним механізмом активації ендотелію все-таки є каскад запальної реакції.

Роль ендотелію та лабораторна оцінка його дисфункції при септичних захворюваннях вивчали в багатьох дослідженнях. Зокрема, оцінювали роль визначення молекул адгезії для оцінки тяжкості та прогнозування наслідків при сепсисі. Переважна більшість досліджень підтверджує їх діагностичне значення [15]. Зокрема, при неонатальному сепсисі рівень Е-селектину суттєво підвищується порівняно із здоровими новонародженими. Його діагностичне значення за площею під ROCкривою становило 0,72 [6]. Відомо, що активація ендотелію починає проявлятись на ранніх стадіях захворювання. Зокрема, у дітей із сепсисом підвищену концентрацію Е-селектину реєструють вже з першої доби захворювання [16]. Концентрація молекул адгезії в крові корелює також з розвитком поліорганної дисфункції при сепсисі у дорослих пацієнтів [1]. Щодо оцінки тяжкості септичного процесу та прогнозу несприятливих наслідків на підставі дослідження показників молекул адгезії на даний час немає переконливих даних. Так, при дослідженні 88 дітей грудного віку із сепсисом автори не виявили залежності між тяжкістю захворювання, летальністю і рівнями ICAM-1, VCAM-1 і Е-селектину [17]. В іншому дослідженні показники VCAM-1 та Е-селектину асоціювались з 28-денною смертністю серед 92 пацієнтів із синдромом системної запальної відповіді (ССЗП) [14]. 
При деяких інших інфекційних захворюваннях вивчали також можливість виявлення/прогнозування ускладнень за допомогою маркерів дисфункції ендотелію. Так, при респіраторних інфекціях, зокрема при пневмонії, рівень Е-селектину у 27 дорослих пацієнтів був незалежним предиктором розвитку респіраторного дистрес-синдрому. При пороговому рівні 40,1 нг/мл чутливість та специфічність тесту становили 0,8 [8].

Щодо інших інфекційних захворювань є повідомлення про вивчення адгезивних молекул при малярії, гарячці Денге та гемолітико-уремічному синдромі на фоні інфекції E. coli O157 : Н7. Зокрема, дослідження хворих на малярію дорослих і дітей свідчать про можливість за допомогою даних маркерів диференціювати тяжкі й ускладнені форми інфекції [4, 12]. Також у дослідженні 212 дітей з малярією високі показники Е-селектину асоціювались з летальністю [18].

При гарячці Денге та інфекції E. coli O157 : H7 ефективність визначення показників молекул адгезії вивчали для діагностики ускладнень, зокрема шоку та гемолітико-уремічного синдрому. Результати проведених досліджень свідчать про певні коливання цих показників, проте виявлені зміни не дозволяють рекомендувати їх для використання в процесі діагностичного інструмента [9, 13].

Таким чином, наші результати та дані досліджень, проведених дотепер, свідчать, що ураження ендотелію при інфекційних захворюваннях пов'язані з етіологічними чинниками і інтенсивністю запальної реакції. Суттєве збільшення показника Е-селектину відбувається при септичному перебігу бактеріальних інфекцій, зокрема при менінгококовій септицемії.

Висновки. 1. Ендотеліальна дисфункція залежить від етіологічного впливу та більш виражена при септичних захворюваннях. 2. Ендотеліальна дисфункція при інфекційних захворюваннях корелює з інтенсивністю запалення. 3. Визначення показника Е-селектину може бути корисним для діагностики бактеріальних інфекцій, диференціальної діагностики вірусних і бактеріальних захворювань та діагностики ускладнень.

$$
\text { Список лі те ратури }
$$

1. Amalakuhan B., Habib S. A., Mangat M., Reyes L. F., Rodriguez A. H., Hinojosa C. A., et al. Endothelial adhesion molecules and multiple organ failure in patients with severe sepsis // Cytokine. - 2016. (88). - S. 267-273.

2. Armstrong S. M., Darwish I., Lee W.L. Endothelial activation and dysfunction in the pathogenesis of influenza A virus infection. // Virulence. - 2013. - № 6 (4). - S. 537-542.

3. Balabanov R., Goldman H., Murphy S., Pellizon G., Owen C., RafolsJ., et al. Endothelial cell activation following moderate traumatic brain injury // Neurological Research. - 2001. - № 2-3 (23). - S. 175-182.

4. Conroy A. L., Lafferty E. I., Lovegrove F. E., Krudsood S., Tangpukdee N., Liles W. C., et al. Whole blood angiopoietin-1 and -2 levels discriminate cerebral and severe (non-cerebral) malaria from uncomplicated malaria // Malaria Journal. - 2009. - № 1 (8). - S. 295.

5. Coureuil M., Join-Lambert O., Lécuyer H., Bourdoulous S., Marullo S., Nassif X. Mechanism of meningeal invasion by Neisseria meningitidis // Virulence. - 2012. - № 2 (3). - S. 164.

6. EdgarJ.D. M., Gabriel V., GallimoreJ. R., McMillan S. A., GrantJ. A prospective study of the sensitivity, specificity and diagnostic performance of soluble intercellular adhesion molecule 1, highly sensitive C-reactive protein, soluble E-selectin and serum amyloid A in the diagnosis of neonatal infection. // BMC pediatrics. - 2010. (10). - S. 22.

7. El-Sayed M. H., Shanab G., Karim A. M., El-Tawil A., Black A., Dixon J. S. Lamivudine facilitates optimal chemotherapy in hepatitis B virus-infected children with hematological malignancies: a preliminary report. // Pediatric hematology and oncology. - 2004. - № 2 (21). - S. 145-156.

8. Fukuda H., Tsuchida D., Koda K., Miyazaki M., Pappas T. N., Takahashi T. Inhibition of sympathetic pathways restores postoperative ileus in the upper and lower gastrointestinal tract // J. of Gastroenterology and Hepatology. - 2007. - № 8 (22), - S. 1293-1299.

9. Khongphatthanayothin A., Phumaphuti P., Thongchaiprasit K., Poovorawan Y. Serum levels of sICAM-1 and sE-selectin in patients with dengue virus infection. // Japanese journal of infectious diseases. - 2006. - № 3 (59). - S. 186-188.

10. Ku C-C., Besser J., Abendroth A., Grose C., Arvin A. M. Varicella-Zoster Virus Pathogenesis and Immunobiology: New Concepts Emerging from Investigations with the SCIDhu Mouse Model // Journal of Virology. - 2005. - № 5 (79). - S. 2651-2658. 
11. Leligdowicz A., Conroy A. L., Hawkes M., Shiboski S., Zhong K., Namasopo S., et al. Markers of Endothelial Injury and Immune Activation Effectively Risk-Stratify Acute Febrile Syndromes in African Children. - 2017. - A2818-A2818 s.

12. Lovegrove F. E., Tangpukdee N., Opoka R. O., Lafferty E. I., Rajwans N., Hawkes M., et al. Serum Angiopoietin-1 and -2 Levels Discriminate Cerebral Malaria from Uncomplicated Malaria and Predict Clinical Outcome in African Children / / PLoS ONE. - 2009. - № 3 (4). - S. e4912.

13. Nevard C. H., Blann A. D.,Jurd K. M., Haycock G. B., Hunt B.J. Markers of endothelial cell activation and injury in childhood haemolytic uraemic syndrome. // Pediatric nephrology (Berlin, Germany). - 1999. - № 6 (13). - S. 487-492.

14. De Pablo R., MonserratJ., Reyes E., Díaz D., Rodríguez-Zapata M., De la Hera, A., Prieto A. VCirculating sICAM-1 and sE-Selectin as biomarker of infection and prognosis in patients with systemic inflammatory response syndrome // European J. of Internal Medicine. - 2013. - № 2 (24). - S. 132-138

15. Page A. V, Liles W.C. Biomarkers of endothelial activation/dysfunction in infectious diseases // Virulence. - 2013. - № 6 (4). - S. 507-516.

16. Paize F., Sarginson R., Makwana N., Baines P. B., Thomson A. P.J., Sinha I., et al. Changes in the sublingual microcirculation and endothelial adhesion molecules during the course of severe meningococcal disease treated in the paediatric intensive care unit // Intensive Care Medicine. - 2012. - № 5 (38). - S. 863-871.

17. Sosa-Bustamante G.P., Amador-Licona N., Barbosa-Sabanero G., Guizar-Mendoza J.M., LópezBriones S., Mulgado-Aguas C.I., et al. Intercellular adhesion molecules and mortality for sepsis in infants younger than 1 year of life. // Revista de investigacion clinica; organo del Hospital de Enfermedades de la Nutricion. - 2012. - № 6 (63). - S. 601-606.

18. Tchinda V. H. M., Tadem A. D., Tako E. A., Tene G., Fogako J., Nyonglema P., et al. Severe malaria in Cameroonian children: correlation between plasma levels of three soluble inducible adhesion molecules and TNF- $\alpha$ // Acta Tropica. - 2007. - № 1 (102). - S. 20-28.

19. Zanoni I., Ostuni R., Marek L. R., Barresi S., Barbalat R., Barton G. M., et al. CD14 controls the LPS-induced endocytosis of Toll-like receptor 4 // Cell. - 2011. - № 4 (147). - S. 868-880.

\section{ПОРАЖЕНИЕ ЭНДОТЕЛИЯ ПРИ ОСТРЫХ ИНФЕКЦИОННЫХ ЗАБОЛЕВАНИЯХ У ДЕТЕЙ И ЕГО ОЦЕНКА С ПОМОЩЬЮ БИОМАРКЁРА Е-СЕЛЕКТИНА}

\section{В. В. Евтушенко, С. А. Крамарев, В. О. Шадрин, Л. В. Закордонеи (Киев)}

Проведено пилотное исследование биомаркёра поражения эндотелия Е-селектина у 55 детей с острыми инфекционными заболеваниями различной этиологии. Показатель Е-селектина достоверно коррелировал с инфекционно-токсическом шоком $\left(R_{\mathrm{pb}}=0,35 ; \mathrm{P}=0,003\right)$ и маркёром воспалительного процесса, C-реактивным белком $(R=0,43 ; \mathrm{P}=0,001)$. Уровень Е-селектина не имел достоверной связи с возрастом пациентов $(\mathrm{R}=-0,197 ; \mathrm{P}=0,369)$, половой принадлежностью $\left(R_{\mathrm{pb}}=0,08 ; \mathrm{P}=0,585\right)$, лечением в отделении интенсивной терапии $\left(R_{\mathrm{pb}}=0,13 ; \mathrm{P}=0,203\right)$, проведением искусственной вентиляции лёгких $\left(R_{\mathrm{pb}}=0,27 ; \mathrm{P}=0,208\right)$, продолжительностью стационарного лечения $(R=0,043 ; \mathrm{P}=0,845)$, уровнем лактатдегидрогеназы в сыворотке крови $(R=-0,09 ; \mathrm{P}=0,49)$, лактата $(R=-0,015 ; \mathrm{P}=0,945)$ и лейкоцитов крови $(R=0,153 ; \mathrm{P}=0,475)$.

Ключевые слова: инфекционные заболевания, эндотелий, эндотелиальная дисфункция, биомаркёр, Е-селектин, дети.

\section{ENDOTHELIAL INJURY IN CHILDREN WITH ACUTE INFECTIOUS DISEASES AND ITS EVALUATION USING BIOMARKER E-SELECTIN}

\section{V. Yevtushenko, S. O. Kramarov, V. O. Shadrin, L. V. Zarkodonets (Kyiv, Ukraine)}

\section{O. O. Bogomolets National Medical University named}

A pilot study of endothelial injury biomarker E-selectin value among 55 children with acute infectious diseases of different etiology was conducted. E-selectin level correlated significantly with the presence of septic shock $\left(R_{\mathrm{pb}}=0.35 ; \mathrm{P}=0.003\right)$ and acute phase inflammatory reactant, C-reactive protein $(R=0.43 ; \mathrm{P}=0.001)$. The level of E-selectin did not have a statistical association with age of patients $(R=-0.197 ; \mathrm{P}=0.369)$, the sex of patients $(R \mathrm{pb}=0.08 ; \mathrm{P}=0.585)$, treatment in the intensive care unit $\left(R_{\mathrm{pb}}=0.13 ; \mathrm{P}=0,203\right)$, mechanical ventilation $\left(R_{\mathrm{pb}}=0,27 ; \mathrm{P}=0,208\right)$, duration of inpatient treatment $(\mathrm{R}=0,043 ; \mathrm{P}=0,845)$, serum LDH level $(R=-0,09 ; \mathrm{P}=0,49)$, serum lactate $(R=-0.015 ; \mathrm{P}=0.945)$ and blood leukocyte levels $(R=0.153 ; \mathrm{P}=0.475)$.

Key words: infectious diseases, endothelium, endothelial dysfunction, biomarker, E-selectin, children. 